\title{
Çok Boyutlu İş Motivasyonu Ölçeğinin Türk Kültürüne Uyarlanması
}

\author{
Studying of Adaptation to Turkish Culture the Multidimensional Work \\ Motivation Scale
}

\section{Aydın ÇİíLíDAĞ $\breve{G}^{*}$ Güçlü ŞEKERCIOĞLU ${ }^{* *}$}

Öz: Bu araştırmanın amacı endüstri ve örgüt psikolojisi alanında sıkça kullanılan ve yedi farklı dilde (İngilizce, Fransızca, Almanca, Çince, Endonezya dili, Norveççe ve Felemenkçe) uyarlaması yapılan çok boyutlu iş motivasyonu ölçeğini (ÇBIMÖ) Türk kültürüne uyarlamak ve araçtan elde edilen puanların psikometrik niteliklerine ilişkin kanıtları ortaya koymaktır. İlişkisel tarama modeli bağlamında yürütülen çalışmada araştırma grubu, farklı hizmet iş kollarında çalışan katılımcılardan (akademisyen, öğretmen, bankacı, otomotiv pazarlama iş göreni, turizm iş göreni ve üniversitede çalışan memurlar) oluşmaktadır. Likert tipi 19 maddeden oluşan ölçme aracı, orijinal kültürde altı faktörlüdür. Uyarlama sürecinde çeviri, geri çeviri yapıldıktan sonra uzman görüşleri alınmış ve öneriler doğrultusunda maddelerde gerekli düzenlemeler yapılmıştır. Bu çerçevede hazırlanan deneme formu için dilsel eş değerlilik çalışması yapılmış ve eşdeğerliliğin sağlandığı belirlenmiştir. Bu aşamada uygulamalar pilot ve asıl uygulama biçiminde yapılmıştır. Pilot uygulamada 166 katılımcıdan elde edilen veri seti üzerinden açımlayıcı ve doğrulayıcı faktör analizleri yapılmış; madde test korelasyonları ve Cronbach alfa iç tutarlılık katsayıları hesaplanmıştır.

Anahtar sözcükler: Çok Boyutlu İş Motivasyonu, Endüstri ve Örgüt Psikolojisi, Psikometrik Nitelikler

\begin{abstract}
The purpose of this research was to adapt the multidimensional work motivation scale (MWMS) into Turkish culture, a scale which is frequently used in industrial and organizational psychology and has already been adapted into seven different languages (English, French, German, Dutch, Indonesian, Chinese, Norwegian) and to reveal evidence in respect to the psychometric properties that were obtained from the collected data. The study was carried out in the context of a relational survey research model and the research group of the study included participants from different service sectors (academic, teacher, bank employer, an employee who works in marketing automotives, the tourism sector and office staff in the university). The scale consisted of 19 Likert type items and six factors in the original culture. In the adaptation process of the scale, translation from English to Turkish and back translation from Turkish to English was done by English lecturers and the necessary regulations were done in accord with the suggestions made by the experts. Therefore the linguistic equivalence study of the pilot form of the scale was done and linguistic equivalence was provided. The applications were made as a pilot and master practices by researchers in this stage.
\end{abstract}

Keywords: Multidimensional Work Motivation, Industrial and Organizational Psychology, Psychometric Properties

\footnotetext{
* Yrd. Doç. Dr., Akdeniz Üniversitesi, Edebiyat Fakültesi, Psikoloji Bölümü, Antalya. aydinc@akdeniz.edu.tr

** Yrd. Doç. Dr., Akdeniz Üniversitesi, Eğitim Fakültesi, Ölçme ve Değerlendirme ABD, Antalya. guclus@akdeniz.edu.tr Bu araştırma Akdeniz Üniversitesi Eğitim Fakültesinde 1-3 Eylül 2016'da gerçekleştirilen V. Eğitimde ve Psikolojide Ölçme ve Değerlendirme Kongresinde (EPOD-2016) sözlü bildiri olarak sunulmuştur.
} 
Çağdaş iş yaşamında örgütsel yapılarda hem yönetim hem de işgören konumunda çalışan insanların birim zamandaki performansları, ne kadar ürettikleri ya da onların iş verimliliğine etki eden faktörlerin neler olduğu bilhassa yönetim biliminde, endüstri ve örgüt psikolojisinde her zaman merak edilmiş ve anlaşılmaya çalışılmıştır. Özellikle sanayi devriminden sonraki süreçte üretimde otomasyona geçilmesi ve kitle üretimine geçilmesi çalışanın ürün üzerindeki doğrudan emeğinin azalmasına yol açarken, bu durum çalışanın hem işinden elde edeceği doyumu azaltıcı bir rol oynamış hem de verimlik üzerinde etkileyici bir faktör olmuştur (Eren 2008, 493). İş yaşamında insan faktörüne bakış açısı değişen sosyal, ekonomik ve üretim koşullarına göre süreç içinde farklılaşmıştır. Klasik yönetim kuramcıları, insanı ekonomik bir varlık olarak görerek maddi tatmini ön plana çıkarmışlardır. Sonrasında neoklasik ve modern yönetim kuramlarını savunanlar ise insanın üretimdeki konumunun yalnızca maddi özellik taşımadığını, maddi olmayan faktörlerden de etkilendiğini ortaya koymuştur. Çalışanların yaptıkları işi önemsemesi, sosyal alışkanlıklar, iş ortamındaki sosyal etkileşimler, ödül ve ceza gibi faktörler çalışanların tepkisinin farklı olmasına yol açmıştır (Ağırbaş et al. 2005, 330). Günümüzde özellikle gelişmiş ülkelerde emek yoğun üretim biçimi geride kaldığı gibi, kol işçiliğinden de bilgi işçiliğine doğru geçiş söz konusudur. Bu gelişmenin doğal sonucu olarak örgütler, çalıştırdıkları işgörenin her an alınıp satılabilecek bir şey olmadığını anlamışlar ve yetişmiş insan gücü için kıyasıya rekabete başlamışlardır. Artık bilgi işçilerini işletmelerinde istihdam etmek isteyen örgütler, sanayi devrimindeki hakim anlayışın tersine, çalışanlarına olumlu ve cazip şartlar sunmaktadır. Bu şartlar yalnızca maddi olanaklarla sınırlı olmayıp, çalışanı motive edecek sosyal olanaklar da sunmaktadır (Kantar 2008, 15).

Örgütler amaçlarına ulaşabilmek için üretim ve hizmetin kalitesi ve miktarında tam olarak etkisi bulunan çalışanların yüksek düzeyde verimli ve üretken olmasını istemektedirler. Bu noktada örgütler için çalışanların motivasyon düzeyleri önemli bir sorundur. Günlük yaşamdaki anlamının ötesinde iş yaşamındaki motivasyon kavramı, çalışanın iş performansı ve verimliliği ile doğrudan ilişkilidir. İş motivasyonu çalışmanın tamamlayıcı bir yönüdür ve aynı zamanda işyerinde bir çalışanın, yeteneklerini artan bir biçimde bir örgüte zaman, para ve kaynakları yönünde adaması, harcamasıdır (Latham 2007, 3). Motivasyon, alternatif gönüllü eylem biçimleri arasından kişi tarafından yönetilen bir seçim süreci olarak tanımlanır (Vroom 1964, 6). Motivasyon, dürtü ve devamlı olarak gerekli hedeflerin yerine getirilmesiyle başarıyı planlamayla örgütsel-politik karar verme becerileriyle bilişsel davranıştaki öğrenme ve değerlendirmeyle önemli ölçüde ilişkilidir (Lee \& Liu 2009, 322). Motivasyon, belirli bir amaç üzerinde insanların istek ve enerjilerini de hedeflemektir. Bu doğrultuda motivasyon, yalnızca işe insanları belirleme rolüne sahip olmamakta, aynı zamanda işlerini yaparken, fiziksel ve akılla ilgili kaynaklarını en uygun biçimde kullanmayı da içermektedir. Bunların da ötesinde motivasyon, işyerlerinde ve özel yaşamlarında insanları etkileyen olumlu enerjinin bir kaynağı olarak da görülebilir (Hauser 2014, 241). Massie ve Douglas, davranışın önemli belirleyicilerinden birinin motivasyon olduğunu öne sürmüşlerdir. Yazarlar açıklamalarında motivasyon dürtülerinin insanı ileri, hedefine doğru hareket ettirdiğini öne sürerek bu durumu şu biçimde formüle etmişlerdir: "motivasyon $\rightarrow$ davranış = performans". Böylelikle bir yönetici, çalışanının hem performansıyla hem de motivasyonuyla ilgili olması gerekmektedir. Kişisel ihtiyaçlar ve bu ihtiyaçların giderilmesi doyumla sonuçlanacak; örgütsel ihtiyaçlar ve bu ihtiyaçların giderilmesi, örgütsel hedeflerin başarılmasıyla sonuçlanacaktır. Bir örgüt ancak çalışanlarını işe motive ederse başarılı olabilir. İş ödülleri, içsel ya da dışsal ödüller olsun, bunlar tamamen çalışanların ihtiyaçlarını karşılayacak biçimde düzenlenmelidir (akt. Padmaja et al. 2013, 50). Motivasyon, çalışanın üretkenliği ve performansında anahtar bir unsurdur. İş motivasyonu genel olarak hem içsel hem de dışsal faktörleri içerir. İçsel faktörler, özellikle bir görev yapma isteğinden, dışsal fak- 
törler ise birey çalışırken görevle ilişkisiz olarak dışarıdan bireyi etkiler. İşyerinde iç motivasyon, takdir, başarı ve yaratıcılık gibi işin kendisinden elde edilen ödülleri gerektirirken; dış motivasyon, parasal ödüller, kazançlar, işyeri özellikleri, meslektaşlarla ve amirlerle ilişkileri ifade eder (Ertaş 2015, 406). İş motivasyonu ilk defa bir dizi enerjik güç anlamında Pinder (1998) tarafından kullanılmıştır ve bu anlamıyla iş motivasyonu bireylerin işle ilişkili davranışları başlatmasının ötesinde, iş davranışının biçimini, yönünü, yoğunluğunu ve sürekliliğini içermektedir (akt. Hsu 2013, 181).

Bazı çalışanların diğerlerine göre işte neden daha fazla çaba sarf ettiğinin anlaşılmaya çalışılması tam olarak örgütün yararına olabilir. Öz-belirleme kuramına (self-determination theory) göre, iş çabasındaki farklılıklar, motive olan çalışanların iş motivasyon türleriyle açıklanabilir. Öz-belirleme kuramı (ÖBK), özerk ve kontrollü motivasyon arasında ayrım yapar. Buna göre iç motivasyon, davranışın özünde tatmin ve zevk deneyimlemek amacıyla bir etkinliğin yapılmasıyla ilgili motivasyon olarak tanımlanır. İç motivasyonu yüksek çalışanlar, eğlenceli, ilginç ve ödüllendirici buldukları için işlerinde çalışılar ki, bu noktada iş yönelimli çalışmalarının vurgulanması gerekir. Aksine dış motivasyonu yüksek olanlar, etkinliğin kendisinden çok etkinliğin neden olduğu sonuçlar üzerinde odaklanırlar. Dış motivasyonun yüksek olması, ödül almak, suçluluktan kaçınmak ya da onaylanmak gibi sonuçları farklı niyeti sürdürmekle ilişkili etkinliklerdir (Dysvik \& Kuvaas 2013, 412-413). ÖBK, farklı gerekçe ve hedeflere dayalı olarak bir eyleme neden olan farklı tipte motivasyonlar arasında ayrım yapmaktadır. En temel ayrım iç ve dış motivasyon arasındadır. İç motivasyon, doğası gereği zevk veya ilgiyle bir şey yapmayı işaret eder. İç motivasyon, eylemin farklı sonuçlarından çok onun özündeki doyum için yapılan bir eylem olarak tanımlanır. İnsanlarda iç motivasyon yalnızca motivasyonun bir biçimi olmayıp, aynı zamanda iradi bir eylemdir. Dış motivasyon ise farklı sonuçlara göre bir şey yapmaya işaret eder. İç motivasyonun aksine dış motivasyon, yapılan eylemdeki eğlenceden çok davranış sonrasında elde edilen sonuca işaret eder. Geleneksel alan yazında dış motivasyon tipik olarak güçlü olsa bile, iç motivasyonun aksine, diş motivasyon güçsüz ve zayıf olarak karakterize edilir (Ryan \& Deci 2000, 55-60). Çok sayıdaki çalışma motivasyonun var olan bu biçimlerini yaşamın farklı alanlarında iş yaşamı da dahil olmak üzere desteklemiştir. Örneğin özerk motivasyon, psikolojik iyi oluşla iş doyumuyla örgütsel ve mesleki bağlllıkla pozitif yönde ilişkilidir. Aksine kontrollü motivasyon, çalışanlar için olumsuz sonuçlarla ilişkilidir. Örneğin iş koliklik, tükenmişlik ve işten ayrılma niyeti gibi (Fernet et al. 2012, 215). ÖBK, insanların öz motivasyonları ve doğal davranışları gereği, meraklı, ilgili, önemli ve başarılı olma yönünde anlayışa sahip olduklarını öne sürer, çünkü başarının kendisi doyum sağlayıcı ve ödüllendiricidir. Ancak kuram, insanların yabancılaşabildiğini, pasif ve etkisiz olabildiğini de ayırt edebilir. ÖBK, motivasyon türleri açısından bu farklılıkları insanların doğal davranışları ve sosyal çevreyle etkileşimleri arasındaki destek ya da engelleme olarak açıklamaktadır. Dış ve içselleştirilmiş düzenlemeler, kontrollü motivasyonların biçimleridir; oysaki kimlikleştirme/ bütünleştirme ve iç düzenleme özerk motivasyonların bir biçimidir. Özerk ve kontrollü motivasyonların tüm türleri motivasyon tipleridir ve kişinin eylem amacını yansıtır. Motivasyonun aksine motive olmama (amotivasyon), eylemdeki amaçsızlığı yansıtır. Özerk ve kontrollü motivasyon üzerine yapılan çok sayıdaki deneysel ve alan araştırma sonuçları tutarlı bir biçimde, devamlılık, daha fazla pozitif etki, performans artması, daha fazla psikolojik iyi oluş, işte daha iyi üretkenlik ve daha az tükenmişlikle ilişkili bulunmuştur (Deci \& Ryan 2008, 14-17).

Tüm bu açıklamalar göstermektedir ki ÖBK, motivasyonu hem düzey hem de özelliğini değerlendirmesine olanak tanıyarak farklı boyutları olan bir kavram olarak öne sürmektedir. ÖBK, motivasyonun üç önemli kategorideki ayrımı ortaya koymaktadır. İlki motive olmama (amotivation), bir eyleme doğru motivasyonun olmamasıyla tanımlanır. İkincisi içsel motivasyon 
(intrinsicmotivation), eylemin kendisi ilginç ve eğlenceli olduğu için bir eylemi kendi isteğiyle yapma olarak tanımlanır. Üçüncüsü dışsal motivasyon (extrinsicmotivation) ise araçsal gerekçeler için bir eylemin düzenlenmesine işaret eder. Örneğin ödül, onay alma, eleştiri ve cezalardan kaçınma, öz saygının arttırılması ya da kişisel olarak değerli bir amaca ulaşma olarak tanımlanır (Gagne et al. 2014, 2).

Motivasyonla ilgili alan yazında çok sayıda farklı motivasyon kuramları (Maslow, McClelland, Herzberg et al.) vardır (Mirabela \& Madela 2013, 1513). Ancak motivasyon konusunda bilim insanları çok sayıda kuram geliştirmiş olmasına rağmen, bu kuramlardan hiç biri insanları motive etmek için tek başına yeterli değildir. Bu kuramlardan biri olan Maslow'un ihtiyaçlar hiyerarşisi yaklaşımı, insanların yaptığı her davranışın belirli ihtiyaçları gidermeye yönelik olduğu ve ihtiyaçların bireyler açısından bir sıralaması olduğu varsayımına dayanır. Maslow'a göre alt kademelerdeki ihtiyaçlar (yaşamsal ihtiyaçlar: hava, su, uyku, yiyecek, cinsellik, güvenlik gibi) giderilmedikçe, üst kademelerdeki ihtiyaçlar (sevgi, aidiyet, saygı, kendini gerçekleştirme) bireyi davranışa yöneltmez. İhtiyaçların insanları davranışa yöneltmesi ihtiyaçların giderilme derecesine bağlıdır (Güney 2014, 365-366). Murray tarafından tanıtılan ikinci bir ihtiyaç kuramı McClelland tarafından geliştirilmiştir. McClelland, hiyerarşiyi görmezden gelerek motivasyonel gücün sıralamalı ayrımı yerine açık bir biçimde başarı, ilişki, güç ve özerkliği içeren ihtiyaçları tanımlamaya odaklanmıştır. McClelland'a göre, herhangi bir zamanda bireyler rekabet etme ihtiyacına sahip oldukları için motivasyonlu davranış bu duruma hizmet etmektedir. McClelland'ın modelinde dikkatlerin çoğu daha fazla başarı gereksinimi ve güç (birinin çevresi üstünde sahip olduğu kontrol ihtiyacı olarak tanımlanır) üzerine odaklanmıştır. McClelland'ın öne sürdüğ̈̈ kavram, Maslow'un (örneğin başarı ihtiyacı yerine kendini gerçekleştirme) aksine açık bir biçimde işyeri davranışlarıyla ilişkili gereksinimler olarak tanımlanmıştır. Böylelikle kuramc1, bireysel faktörler üzerinde iş motivasyonunun etkisini araştırmayı oldukça önemli bulmuştur. Maslow, McClelland ve meslektaşları motivasyonda bireysel farklılıkların rolü üzerinde odaklanırken; Herzberg, iş etkinliklerinin, işin doğası ve performansa nasıl etkide bulunduğunu öne sürdügü motivasyon-hijyen kuramında ortaya koymaya çalışmıştır (Steers et al. 2004, 381). Herzberg'in motivasyon-hijyen kuramına göre, motive edici faktörler çalışanların işleri ile ilgili kendilerini iyi hissetmelerini sağlarken, bundan farklı olarak hijyen faktörler, çalışanların işleri hakkında kendilerini kötü hissetmelerine neden olmaktadır. İş doyumlu çalışanlar, doyumlarını iç faktörlere bağlarlar, memnuniyetsiz çalışanlar ise davranışlarını dış faktörlere bağlarlar. Motive edici olarak adlandırılan faktörler, çalışanların doyumlarına katkı sağlayan bir rol oynarken, hijyen faktörler iş memnuniyetsizliğine yol açar. Bu iki faktör iç (internal) ve diş (external) faktörler olarak adlandırılır (Padmaja et al. 2013, 56).

Alanyazında çok sayıda motivasyon kuramı bulunmasının nedeni, insanın doğasının giriftliğinin getirdiği özellik nedeniyle insanın motivasyonunun da karmaşıklı̆̆ 1 ve çok yönlü olmasındandır. Örneğin motivasyonun bazı öğeleri, çalışanın içsel koşullarından kaynaklanırken, bazı unsurlar kişinin dışındadır; bazıları rasyonel/bilişsel karar vermeyi içerirken bazıları daha duygusaldır (Riggio 2014, 211).

İş motivasyonunun çalışma yaşamında çok sayıda olguyla ilgili olması nedeniyle araştırmacılar tarafindan iş motivasyonu olgusu birçok değişkenle ilişkili olarak incelenmiştir. Çal1şanların iş motivasyonlarıyla ilgili yapılan araştırmalarda iş motivasyonu ile iş doyumu, çalışanın bireysel olarak işe ne kattığı ve ödül olarak işten ne aldığı, liderlik desteği, iletişim, kültürel boyutlar, psikolojik güçlendirme, yaşam doyumu, duygusal tükenmişlik, işe bağlllık, psikolojik durumu açıklayan işin anlamlılığı, işin sorumluluğu ve iş performansı arasında önemli ilişkiler bulunmuştur (Fernet et al. 2012, 223; Mirabela \& Madela 2013, 1518; Abd-El-Salam et al. 
2013, 44; Mafini \& Dlodlo 2014, 10; Guo et al. 2014, 737; Riggio 2014, 226-227; Toode et al. 2014, 366; Lazaroiu 2015, 101).

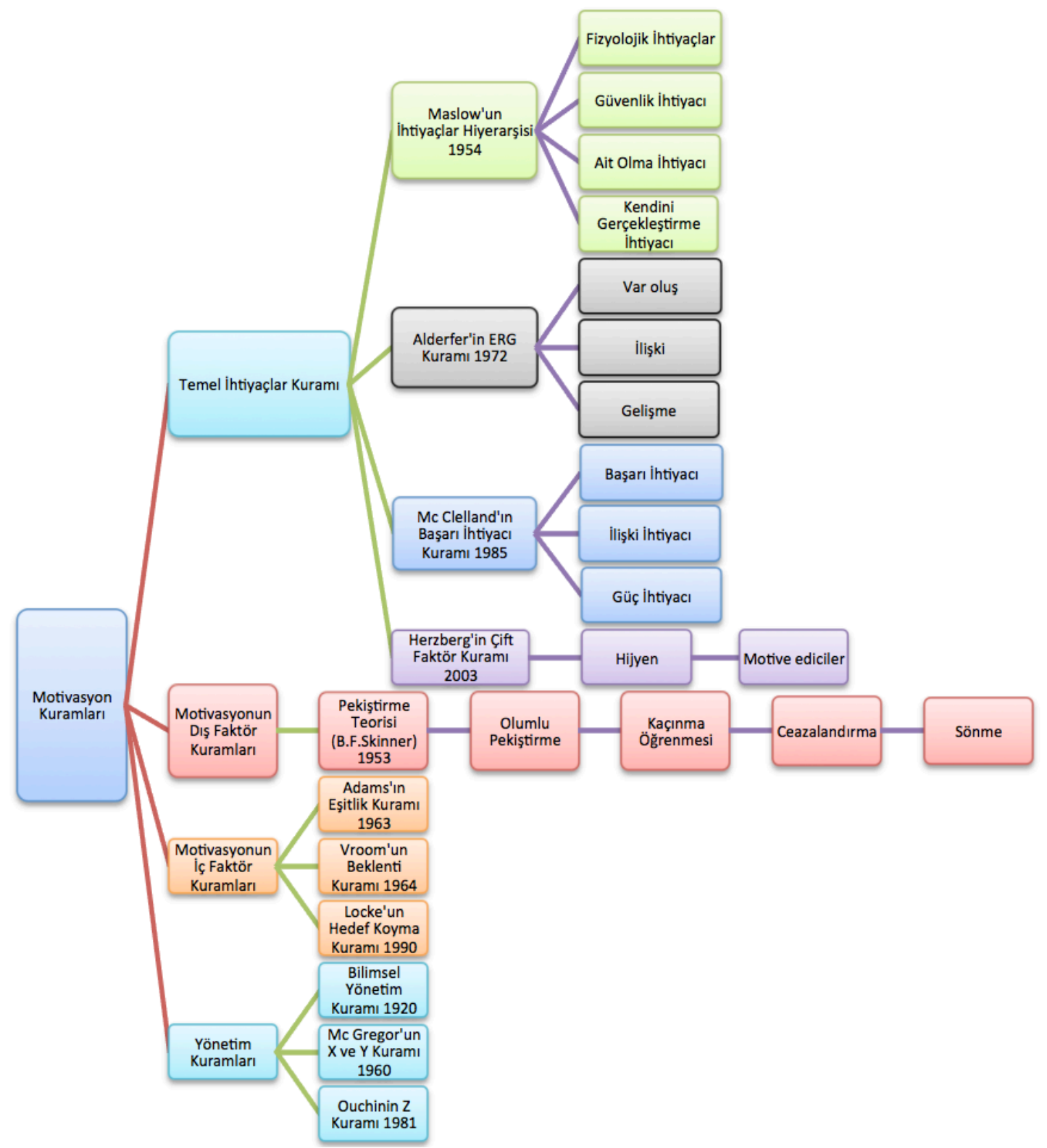

Şekil 1. Motivasyon Kuramları (Hauser 2014, 245)

2009'da Gallup Enstitüsü tarafından Alman Şirketlerindeki 1900 çalışanın katılımıyla gerçekleştirilen betimsel bir araştırmada elde edilen sonuçlar, çalışanların motivasyonlarına yönelik önemli bilgiler ortaya koymuştur. Araştırmada çalışanların yaklaşı \% \%90'1 kendilerini işverenlerine karşı borçlu hissetmedikleri ve işte katı bir biçimde görevlerin yönetim tarafindan belirlendiği, yalnızca çalışanların \%13'ünün görevlerini şirketle birlikte belirledikleri, çalışanların $\% 67$ 'sinin gerekli işleri yaparken katı bir biçimde sınırlandırıldıkları ve gönüllü işlerden ve özel çabalardan sakındıkları, çalışanların \%5'inin de tümüyle motive olmadığı belirlenmiştir. Çalışanların motive olmamalarının altında yatan temel gerekçe, sorumluluk durumundaki mesleki yetkisizlikleri, bu kısıtlamanın, çalışanlarda iş potansiyellerinin uygunsuz kullanımı, mesleki becerilerinin teşvik edilmemesidir (Hauser 2014, 239-240). 
Hemen hemen her örgüt yöneticisi örgütsel amaçlara ulaşmak için daima çalışanlarının motivasyon düzeyleriyle ilgilidir. Ancak iş motivasyonuyla ilgili hem objektif ve standardizasyonu yapılmış ölçme araçlarının geliştirilmemiş olması, hem de motivasyonun tüm boyutlarını kapsayacak ölçek olmaması nedeniyle yakın zamana kadar iş motivasyonunun ölçülmesi önemli bir sorun olmuştur. Bireylerin motivasyonel gereksinimlerini değerlendirmek için önceki yıllarda tematik algı testi (TAT) bazı araştırmacılar tarafindan kullanılmış, ancak bu testin değerlendirilme aşamasının öznel yorumlar gerektirmesi nedeniyle çoğu zaman güvenilmeyen sonuçlarla karşılaşılmıştır. Bu nedenle alternatif olarak daha güvenilir sonuçlar ortaya koyan öz-bildirim ölçeklerinin iyi sonuçlar verdiği söylenebilir (Riggio 2014, 193). Bu araştırmada gerek Türkçe alanyazında iş motivasyonu ile ilgili geliştirilen ölçeklerin yetersiz olması gerek iş motivasyonunun çok sayıda alt boyuttan oluşması ve gerekse farklı iş alanlarında çalışan beyaz yakalılara yönelik Türkçe psikometrik nitelikleri iyi bir ölçme aracının bulunmaması bu çalışmanın yapılmasına zemin hazırlamıştır. Örneğin Endüstri Psikolojisi alanında kullanılan testlerle ilgili Dündar, Özutku ve Taşpınar'ın 2007'de yaptıkları bir araştırmada, Mottaz'ın (1985) motivasyon envanteri (motivation inventory) adında geliştirdiği ölçeğin, 402 Turizm çalışanına uygulanarak Türk kültürüne uyarlandığı belirlenmiştir. Uyarlanan bu motivasyon ölçeği, içsel ve dişsal motivasyon alt boyutlarına sahip olup, 24 maddeden oluşan Likert tipi bir araçtır (Çelik \& Telman 2013, 162-164). Uyarlanan bu motivasyon ölçeğinin hem tek iş kolundan (turizm çalışanları) örneklem alınarak oluşturulması hem de yalnızca motivasyonun içsel ve dışsal boyutlarıyla ilgili ölçme yapması aracın sınırlı yönleridir. Dolayısıyla bu çalışma sonucunda daha önce dokuz farklı ülkede (Kanada, Belçika, Fransa, Senegal, İngiltere, Norveç, İsviçre, Çin ve Endonezya) yedi dile uyarlanmış olan çok boyutlu iş motivasyonu ölçeğinin (ÇBIMÖ) farklı hizmet kollarında çalışanlara uygulanarak, Türk kültürüne uyarlanması amaçlanmıştır. Böylelikle endüstri ve örgüt psikolojisi alanında çalışan araştırmacıların iş motivasyonunu çok boyutlu olarak ölçmelerinin yanı sıra farklı hizmet kollarında çalışanlara da ölçek uygulama olanağı sağlanmış olacaktır.

\section{Yöntem}

Araştırma ilişskisel tarama modeli bağlamında yapılmıştır. İlişkisel tarama modelinde geçmişte ya da hâlen var olan bir durumu var olduğu biçimde betimlemeyi amaçlayan tarama modeli kapsamında, korelasyon türünden tarama yapmak olanaklıdır (Karasar 1994, 81)

Araştırma Grubu: Pilot ve asıl uygulama bağlamında farklı hizmet iş alanlarında çalışan katılımcılardan oluşmaktadır. Hem pilot hem de asıl uygulamada araştırma grubu uygun örnekleme yöntemi ile seçilmiştir. Pilot uygulamada katılımcı sayısı 166, asıl uygulamada ise 506' dır. ÇBIMMÖ' nün asıl uygulamasında Antalya il merkezindeki altı farklı hizmet iş alanındaki meslek çalışanlarına (akademisyen, öğretmen, bankacı, otomotiv pazarlama iş göreni, turizm iş göreni ve üniversitede çalışan memurlar) ulaşılmıştır. Antalya ilinin sosyo-ekonomik yapısı endüstri üretiminden çok hizmet iş alanına yönelik olması nedeniyle araştırma grubunda yer alan katılımcılar, hizmet iş alanının farklı iş kollarındaki çalışanlarından oluşturulmuştur. Araştırma grubunun demografik özellikleri ile ilgili ayrıntılı bilgi aşağıda Tablo 1'de sunulmuştur. 
Katılımcıların demografik değerleri incelendiğinde, çalışmaya katılan kadın (\%54.5) ve erkeklerin $(\% 45.5)$ oranlarının birbirine yakın olduğu söylenebilir. Yaş dağılımına göre 28-37 yaş (\%41.1) grubundaki katılımciların diğerlerine göre oransal olarak daha fazla yer aldığı, medeni duruma göre katılımcıların ağırlıklı olarak evli olduğu (\%64.6), eğitim durumuna göre katılımcıların önemli ölçüde lisans mezunu olduğu (\%56.9), çalış1lan sektöre göre katılımcıların büyük oranda kamuda çalıştığ 1 (\%61.5), iş alanına göre katılımcıların önemli kısmının öğretmen olduğu (\% 43.5), çalışma düzenine göre ağırlıklı olarak sabit mesaili çalışan oldukları (\%96.4) ve çalışma biçimine göre katılımcıların büyük oranda kadrolu çalışan oldukları (\%76.5) görülmektedir.

Veri Toplama Aracı: Gagné, Forest, Gilbert, Aubé, Morin ve Malorni tarafindan 2010 yılında geliştirilen Çok Boyutlu İş Motivasyonu Ölçeği (ÇBİMÖ) Likert tip olup, 19 maddeden oluşmaktadır. Her bir maddeye ilişkin cevaplama 7 derece üzerinden hiç uygun değil (1), çoğunlukla uygun değil (2), uygun değil (3), orta (4), uygun (5), oldukça uygun (6) ve tamamen uygun (7) arasında yapılmaktadır. Ölçek orijinalinde altı alt ölçekten oluşmaktadır. Bu alt ölçekler motive olmama (amotivation), dişsal düzenleme-sosyal (extrinsic regulation social), dışsal düzenleme-maddesel (extrinsic regula-

Tablo 1. Katılımcılara İlişkin Demografik Değerler

\begin{tabular}{|l|c|c|}
\hline Cinsiyet & f & $\%$ \\
\hline Kadın & 276 & 54.5 \\
\hline Erkek & 230 & 45.5 \\
\hline Yaş & & \\
\hline $18-27$ & 83 & 16.4 \\
\hline $28-37$ & 208 & 41.1 \\
\hline $38-47$ & 149 & 29.4 \\
\hline 48 ve üzeri & 66 & 13.0 \\
\hline Medeni Durum & & \\
\hline Evli & 327 & 64.6 \\
\hline Bekar & 179 & 35.4 \\
\hline Ĕgitim & & \\
\hline İlkokul & 4 & 0.8 \\
\hline Ortaokul & 4 & 0.8 \\
\hline Lise & 45 & 8.9 \\
\hline Ön Lisans & 48 & 9.5 \\
\hline Lisans & 288 & 56.9 \\
\hline Lisans üstü & 117 & 23.1 \\
\hline Sektör & & \\
\hline Kamu & 311 & 61.5 \\
\hline Özel & 195 & 38.5 \\
\hline İş Alanı & & \\
\hline Turizm & 46 & 9.1 \\
\hline Otomotiv Satış & 66 & 13.1 \\
\hline Akademisyen & 86 & 17.0 \\
\hline Öğretmen & 220 & 43.5 \\
\hline Memur & 34 & 6.7 \\
\hline Bankacı & & \\
\hline Belediye Çalışanı & 33 & 23.5 \\
\hline Çalışma Düzeni & & \\
\hline Sabit Mesai & 488 & \\
\hline Vardiyalı & & \\
\hline Çalışma Biçimi & & \\
\hline Kadrolu & & \\
\hline Sözleşmeli & & \\
\hline
\end{tabular}
tion material), içe yansıtılan düzenleme (introjected regulation), kişisel düzenleme (identified regulation) ve içsel motivasyondur (intrinsic motivation).

İlk olarak Kanada'da İngilizce ve Fransızca olarak geliştirilen ÇBİMÖ dört alt ölçekten oluşmaktadır. Bunlar içsel motivasyon (intrinsic motivation), kişisel düzenleme (identified regulation), içe yansıtılan düzenleme (introjected regulation) ve dişsal düzenlemedir (external motivation). ÇBIMÖ'nün dört faktörlü deseninin psikometrik niteliklerini ortaya koymak amaciyla araç toplam 1644 iş görene (İngilizce form için $n=1115$, Fransızca form için $n=529$ ) uygulanmış ve bu katılımcılardan elde edilen veriler doğrultusunda doğrulayıcı faktör analizi (DFA) yapılmış, Cronbach Alfa iç tutarlılık katsayıları hesaplanmış ve her iki form için ölçme değişmezliği (measurement invariance) çalışılmıştır. İngilizce form için yapılan DFA sonucunda uyum indeksleri $\mathrm{S}-\mathrm{B} \chi^{2}(49)=$ 450.43, $\mathrm{p}=.000, \chi^{2} / \mathrm{sd}=9.19, \mathrm{CFI}=.92, \mathrm{RMSEA}=.086$; Fransızca form için yapılan DFA sonucunda uyum indeksleri $\mathrm{S}-\mathrm{B} \chi^{2}(49)=166.56, \mathrm{p}=.000, \chi^{2} / \mathrm{sd}=3.4, C F I=.96, R M S E A=.067$ olarak bulunmuştur. İngilizce form için alfa katsayılarının .71 ile .86 ve Fransızca form için alfa katsayılarının .70 ile .87 arasında değiştiği belirlenmiştir. Ayrıca her iki form için ölçme değiş- 
mezliğinin sağlandığı ortaya konmuştur (Gagné et al. 2010, 636).

Orijinal aracın geliştirilmesi sürecinde madde havuzunda başlangıçta 55 maddesi olan ÇBIMÖ için başka kültürlerdeki diğer beş yazar tarafindan yeni maddeler eklenmiştir. Bu maddeler Kanada'da Fransızca ve İngilizce, Belçika'da Felemenkçe olarak, heterojen bir iş gören grubuna $(\mathrm{n}=500)$ uygulanmış ve elde edilen veri üstünden açımlayıcı faktör analizi (AFA) yapılmış, maddeler arası ilişkiler incelenmiştir. Böylece ÇBIMMÖ’nün altı faktörlü yapısı ortaya konmuştur. Ayrıca bu uygulamalara ek olarak aynı çalışmada Norveççe, Almanca, Çince ve Endonezya dili için uygulamalar yapılmış, aracın psikometrik nitelikleri sorgulanmıştır. Fransızca, İngilizce ve Felemenkçe form uygulamalarından elde edilen veri seti için yapılan DFA sonucunda 790 kişiye uygulanan Fransızca form için uyum indeksleri S-B $\chi^{2}(141)=463.94$, $\chi^{2} / \mathrm{sd}=3.29, C F I=.93, R M S E A=.054 ; 568$ kişiye uygulanan İngilizee form için uyum indeksleri $\mathrm{S}-\mathrm{B} \chi^{2}(141)=509.96, \chi^{2} / \mathrm{sd}=3.62, C F I=.90, R M S E A=.068 ; 530$ kişiye uygulanan Felemenkçe form için uyum indeksleri $\mathrm{S}-\mathrm{B} \chi^{2}(141)=231.78, \chi^{2} / \mathrm{sd}=1.64, C F I=.97, R M S E A=.035$ olarak bulunmuştur. Ayrıca standardize edilmiş katsayıların .48 ile .96 arasında; gizil değişkenler arasındaki korelasyonların Fransızca form için -.45 ile .82; İngilizce form için -.53 ile .80; Felemenkçe form için -.38 ile .75 arasında değiştiği belirlenmiştir. Bunlara ek olarak Almanca form için yapılan DFA sonucunda uyum indeksleri S-B $\chi^{2}(140)=231.84, \chi^{2} / \mathrm{sd}=1.66, C F I=.92$, RMSEA=.059; Çince form için yapılan analiz sonucunda uyum indeksleri S-B $\chi^{2}(140)=304.3$, $\chi^{2} / \mathrm{sd}=2.17, C F I=.94, R M S E A=.078$ olarak bulunmuştur (Gagné et al. 2014, 183).

Verilerin Toplanması ve Işslem: ÇBİMÖ’nün uyarlanması için öncelikle araştırmacılar tarafından ölçeğin farklı dillerde ve ülkelerde geliştirilmesi ve uyarlanması çalışmasını yapan ekibin başı Marylene Gagne'den e-posta aracılığıyla ölçeğin Türk kültürüne uyarlanması için yazılı izin istenmiştir. Alınan iznin ardından Akdeniz Üniversitesi Bilimsel Araştırma ve Yayın Etiği kurulundan araştırmanın bilimsel etiğe uygunluğuna ilişkin başvuru yapılmış ve yazılı onay istenmiştir. Alınan bilimsel etiğe uygunluk onay yazısından sonra araştırma üç aşamalı olarak gerçekleştirilmiştir. Birinci aşamada ölçeğin dilsel eşdeğerlilik çalışması, ikinci aşamada pilot (ön) uygulama ve üçüncü aşamada ise asıl (gerçek) uygulama yapılmıştır. Üç aşamada da araştırmaya katılımda gönüllülük esas alınmıştır.

Araştırmanın birinci aşamasında dilsel eşdeğerliliği belirlemek için Akdeniz Üniversitesi Yabancı Diller Bölümünden 31 İngilizce okutmanına ölçeğin önce İngilizce formu uygulanmış, dört hafta sonra aynı gruba ölçeğin Türkçe formu uygulanmıştır. Elde edilen veri setinde dağılımların normale yakın olması nedeniyle hesaplanan Pearson korelasyonunun pozitif, yüksek ve anlamlı olduğu belirlenmiştir, $\mathrm{r}=.76, \mathrm{p}=.000$ Dilsel eşdeğerlilik kanıtı için ayrıca bağımlı gruplar için t-testi yapılmış, İngilizce ve Türkçe formlardan elde edilen puan ortalamaları arasında manidar bir fark olmadığı belirlenmiştir, t(30)=.177, p=.861 Bu sonuçlar çerçevesinde ÇBİMÖ’nün dilsel eşdeğerliliğinin sağlandığı kararı alınmıştır.

İkinci aşamada ölçeğin pilot uygulaması gerçekleştirilmiştir. Ölçek altı farklı meslekten (psikolog, öğretmen, otomotiv pazarlama iş göreni, turizm iş göreni, sağlık otomotiv pazarlama iş göreni, devlet memuru) ve farklı demografik özelliklerden oluşan 166 iş görene uygulanmıştır. Pilot uygulamadan elde edilen veriler için AFA ve DFA yapılmış, madde ayırt edicilikleri hesaplanmış ve çalışmayan maddeler, uzman görüşü de alınarak, yeniden düzenlenmiştir. $\mathrm{Bu}$ düzenlemenin ardından asıl uygulamaya geçilmiştir.

Son olarak üçüncü aşama ölçeğin uyarlama çalışması için asıll uygulamanın yapıldığı aşamadır. Bu aşamada ölçek 647 katılımcıya uygulanmıştır. Veri setinde AFA ve DFA'nın sayıltıları test edilmiş, 141 katılımcıya ait verilerin veri setinden çıkarılmasına karar verilmiştir. Böylece 
506 katılımcıdan elde edilen veri seti doğrultusunda yapı geçerliliğine ilişkin kanıt elde etmek amacıyla faktör analizleri yapılmış, iç tutarlılık bağlamında güvenilirlik kanıtı elde etmek amacıyla ise Cronbach Alfa katsayıları hesaplanmıştır.

Verilerin Analizi: ÇBİMÖ’nün psikometrik niteliklerine ilişkin analizlere geçilmeden dağ 11 mın normalliğine, uç değerlere, çoklu bağlantı (multi collinearity) ve kayıp değer problemine ilişkin sayıltılar test edilmiştir. Bu analizlerin ardından dilsel eşdeğerlilik çalışması için Pearson korelasyonu hesaplanmış ve bağımlı gruplar için t-testi yapılmıştır. Pilot ve asıl uygulamalardan elde edilen veri setleri üstünden $A F A$ ve $D F A$ yapılmış, alt ölçekler düzeyinde Cronbach Alfa katsayıları hesaplanmıştır.

\section{Bulgular}

ÇBIMÖ'nün yapı geçerliliğine ilişkin kanıt elde edebilmek amacıyla AFA yapılmıştır. AFA öncesinde örneklem büyüklüğünün faktörleştirmeye uygunluğunu test etmek amaciyla KaiserMeyer-Olkin (KMO) testi uygulanmıştır. Analiz sonucunda KMO değerinin .83 olduğu belirlenmiştir. Bu bulgu doğrultusunda, faktör çıkartmak için örneklem büyüklügünün "iyi" olduğu söylenebilir (Çokluk et al. 2016, 207). Ayrıca Bartlett küresellik testi sonuçları incelendiğinde, elde edilen ki-kare değerinin manidar olduğu görülmüştür, $\chi^{2}(171)=3446.62, p=.000 \mathrm{Bu}$ doğrultuda, verilerin çok değişkenli normal dağglımdan geldiği kabul edilmiştir.

ÇBIMÖ'nün faktör desenini ortaya koymak amaciyla faktörleştirme yöntemi olarak temel bileşenler analizi; döndürme yöntemi olarak da dik döndürme yöntemlerinden maksimum değişkenlik (varimax) seçilmiştir.

Yapılan analiz sonucunda, analize temel olarak alınan 19 madde için öz değeri 1'in üzerinde olan altı bileşen olduğu görülmüştür. Bu bileşenlerin toplam varyansa yaptıkları katk1 \%64.05'tir. Altı faktör için tekrarlanan analizde, maddeler, binişiklik ve faktör yük değerlerinin kabul düzeyini karşılayıp karşılamaması açısından değerlendirildiğinde, binişik ve faktör yük değeri düşük bir madde olmadığı, ancak içe yansıtılan düzenleme alt ölçeğine ait 19. maddenin (Kendimi kanttlamak zorunda olduğum için işimde çaba sarf ediyorum.) dışsal düzenleme-maddesel faktörü altında yer aldığı belirlenmiştir. Gerek orijinal kültürdeki faktör deseni açısından tutarsızlık olmaması gerekse faktör isimlendirmede sorun yaratması nedeniyle bu madde analiz dişı bırakılmıştır. Bu işlemin ardından elde edilen faktör deseni, maddelerin faktör yük değerleri ve ortak faktör varyansları Tablo 2'de sunulmuştur.

Tablo 2. ÇBIMÖ'nün Faktör Deseni (Temel Bileşenler Analizi-Varimax)

\begin{tabular}{|l|c|c|c|c|c|c|c|}
\hline Maddeler & $\mathbf{F 1}^{\mathbf{a}}$ & $\mathbf{F} \mathbf{2}^{\mathbf{b}}$ & $\mathbf{F} \mathbf{F}^{\mathbf{c}}$ & $\mathbf{F 4}^{\mathbf{d}}$ & $\mathbf{F 5}^{\mathbf{e}}$ & $\mathbf{F 6}^{\mathbf{f}}$ & $\mathbf{h}^{\mathbf{g}}$ \\
\hline $\begin{array}{l}\text { 8. İşimde çaba sarf etmenin benim için özel bir anlamı var. } \\
.815\end{array}$ & -.026 & -.012 & -.104 & .105 & .182 & .720 \\
\hline $\begin{array}{l}\text { 10. Bu iş, kişisel değerlerimle uyumlu olduğu için } \\
\text { işimde çaba sarf ediyorum. }\end{array}$ & .814 & -.041 & -.013 & -.069 & .181 & .130 & .719 \\
\hline $\begin{array}{l}\text { 12. Bu işte çaba sarf etmenin kişisel olarak önemli } \\
\text { olduğunu düşündüğ̈m için işimde çaba gösteriyorum. }\end{array}$ & .596 & -.131 & .027 & -.248 & .451 & .090 & .646 \\
\hline $\begin{array}{l}\text { 13. Ancak işimde yeterince çaba sarf edersem başkaları } \\
\text { (işveren, amir vb.) beni ekonomik olarak ödüllendirirler. }\end{array}$ & -.016 & .813 & .204 & .025 & -.063 & -.017 & .708 \\
\hline $\begin{array}{l}\text { 17. İşimde yeterince çaba sarf etmezsem işimi kaybetme } \\
\text { riskim olur. }\end{array}$ & -.076 & .802 & .114 & .013 & .177 & -.096 & .703 \\
\hline $\begin{array}{l}\text { 15. İşimde yeterince çaba sarf edersem başkaları (işve- } \\
\text { ren, amir vb.) bana daha fazla iş güvenliği sağlarlar. }\end{array}$ & .031 & .788 & .301 & .001 & .093 & .029 & .722 \\
\hline 9. Başkalarının (amir, meslektaş, aile vb.) bana daha & .086 & .243 & .836 & -.009 & -.004 & -.029 & .766 \\
\hline
\end{tabular}




\begin{tabular}{|c|c|c|c|c|c|c|c|}
\hline fazla saygı duyması için işimde çaba sarf ediyorum. & & & & & & & \\
\hline $\begin{array}{l}\text { 11. Başkalarının (amir, meslektaş, aile vb.) bana yönelik } \\
\text { eleştirilerinden kaçınmak için işimde çaba sarf ediyorum. }\end{array}$ & -.117 & .158 & .797 & .143 & .070 & -.032 & .700 \\
\hline $\begin{array}{l}\text { 7. Başkalarının (amir, meslektaş, aile vb.) onayını almak } \\
\text { için işimde çaba sarf ediyorum. }\end{array}$ & .025 & .189 & .776 & .122 & -.068 & .131 & .675 \\
\hline $\begin{array}{l}\text { 1. Zamanımı israf ettiğimi düşündüğüm için işimde çaba } \\
\text { sarf etmiyorum. }\end{array}$ & -.051 & .064 & -.019 & .813 & -.067 & .057 & .676 \\
\hline $\begin{array}{l}\text { 3. Çaba sarf etmeye değer olmadığını düşündüğüm için } \\
\text { işimde az çaba gösteriyorum. }\end{array}$ & -.149 & -.014 & .078 & .775 & -.248 & -.008 & .691 \\
\hline $\begin{array}{l}\text { 5. İşim anlamsız olmasına rağmen neden hala bu işi } \\
\text { yaptığımı bilmiyorum. }\end{array}$ & -.133 & -.025 & .223 & .733 & -.107 & -.096 & 626 \\
\hline $\begin{array}{l}\text { 16. Şimdiki işimde çaba sarf ederim aksi halde, kendimi } \\
\text { mahcup hissederim, }\end{array}$ & .078 & .166 & .033 & -.110 & .855 & -.042 & .780 \\
\hline $\begin{array}{l}\text { 14. İşimde çaba sarf ederim aksi halde, kendimi kötü } \\
\text { hissederim. }\end{array}$ & .298 & -.024 & -.062 & -.247 & .756 & .126 & .742 \\
\hline $\begin{array}{l}\text { 18. İşim, kendimle gurur duymamı sağladığı için işim- } \\
\text { de çaba sarf ediyorum. }\end{array}$ & .421 & .151 & .019 & -.129 & .529 & .134 & .515 \\
\hline 4. Heyecan verici olduğu için işimde çaba sarf ediyorum. & .193 & -.010 & .092 & -.071 & .055 & .850 & .776 \\
\hline 2. İlginç olduğu için işimde çaba sarf ediyorum. & .011 & -.186 & -.017 & .124 & .080 & .821 & .731 \\
\hline $\begin{array}{l}\text { 6. İşimi yaparken eğlendiğim için işimde çaba sarf } \\
\text { ediyorum. }\end{array}$ & .418 & .173 & -.015 & -.146 & -.010 & .650 & 649 \\
\hline
\end{tabular}

Yapılan analiz sonucunda, orijinal kültürde faktörler altında tanımlanan maddelerin, hedef kültürde de aynı biçimde toplandığ 1 belirlenmiştir. Tablo 2'de görüldüğü üzere, alt ölçekler düzeyinde faktör yük değerleri a) kişisel düzenleme alt ölçeği için .60 ile .82 arasında, b) dışsal düzenleme-maddesel alt ölçeği için .79 ile .81 arasında, c) dışsal düzenleme-sosyal alt ölçeği için .78 ile .84 arasında, d) motive olmama alt ölçeği için .73 ile .81 arasında, e) içe yansıttlan düzenleme alt ölçeği için .53 ile .86 arasında ve f) içsel motivasyon alt ölçeği için .65 ile .85 arasında değişmektedir. Faktör yük değerleri büyüklük açısından incelendiğinde, yük değerlerini “iyi”den "mükemmel”e doğru nitelendirmek olanaklıdır(Tabachnick \& Fidell 2015, 654). Maddelerin ortak faktör varyansları incelendiğinde ise tüm değerlerin .20'nin üstünde olduğu; üç madde haricinde değerlerin .66'nın üstünde olduğu ve ortak faktör varyanslarının .52 ile .78 arasında değiştiği görülmektedir. Diğer bir ifadeyle maddelerin varyansa yaptıkları katkının genellikle yüksek olduğu söylenebilir (Büyüköztürk 2011, 125; Çokluk et al. 2016: 240). Faktörlerin toplam varyansa yaptıkları katkının a) kişisel düzenleme alt ölçeği için \%23.38, b) dışsal düzenleme-maddesel alt ölçeği için $\% 17.79$, c) dışsal düzenleme-sosyal alt ölçeği için $\% 11.33$, d) motive olmama alt ölçeği için $\% 6.56$, e) içe yansıtılan düzenleme alt ölçeği için $\% 6.07$ ve f) içsel motivasyon alt ölçeği için $\% 4.75$ olduğu; açıklanan toplam varyansın $\% 69.88$ olduğu belirlenmiştir. Analize dâhil edilen değişkenlerle ilgili toplam varyansın 2/3'ü kadar miktarının ilk olarak kapsadığı faktör sayısı, önemli faktör sayısı olarak değerlendirilir. Uygulamada, özellikle sosyal bilimlerde ölçek geliştirmede, sözü edilen miktara ulaşmak güç olmakla birlikte çok faktörlü desenlerde, açıklanan varyansın $\% 40$ ile $\% 60$ arasında olması yeterli olarak kabul edilir (Büyüköztürk 2011, 125; Gorsuch 1974). Bu çerçevede açıklanan toplam varyansın yeterli olduğu ifade edilebilir.

ÇBIMÖ'nün yapı geçerliliğine ilişkin ek kanıt üretmek amacıyla DFA yapılmıştır. Yapılan 
analiz sonucunda standardize edilmiş katsayılar ve hata varyansları Şekil 2'de verilmiştir.

Şekil 2'de görüldüğü üzere, ÇBIMÖ’nün standardize edilmiş katsayıları 40 ile .84 ve hata varyansları ise .30 ile .84 arasında değişmektedir. Modelde bir modifikasyon yapılmış (2. ile 4. göstergeler arasında), yapılan modifikasyonun kikare’ye manidar katkı sağladığı belirlenmiştir. Modele ilişkin uyum indekslerinin $\chi^{2}(119)=330.07$, $\mathrm{p}=.000, \chi^{2} / \mathrm{sd}=2.77, \mathrm{RMSEA}=.059, \mathrm{GFI}=.93$, AGFI $=$ $.90, S R M R=.59$ ve $C F I=.96$ olduğu tespit edilmiştir. Ayrıca göstergelere ilişkin standardize edilmiş katsayıların bir madde haricinde (söz konusu 19. maddenin hata varyansı da yüksektir) $t$ değerlerinin anlamlı olduğu (7.69 ile 23.99 arasında) belirlenmiştir.

Alt ölçek puanları açısından iç tutarlılık bağlamında güvenilirliği belirlemek amacıyla Cronbach alfa hesaplanmıştır. Buna göre alfa katsayılarının motive olmama alt ölçeği için .72 içsel motivasyon alt ölçeği için .73, dışsal düzenleme-sosyal alt ölçeği için .78, kişisel düzenleme alt ölçeği için .76, dışsal düzenleme-maddesel alt ölçeği için .80 ve içe yansitılan düzenleme alt ölçeği için .73 olduğu belirlenmiştir.

\section{Sonuç}

$\mathrm{Bu}$ çalışma sonucunda ÇBIMÖ'den elde edilen puanların yap1 geçerliliğine ilişkin $A F A$ bulgula-

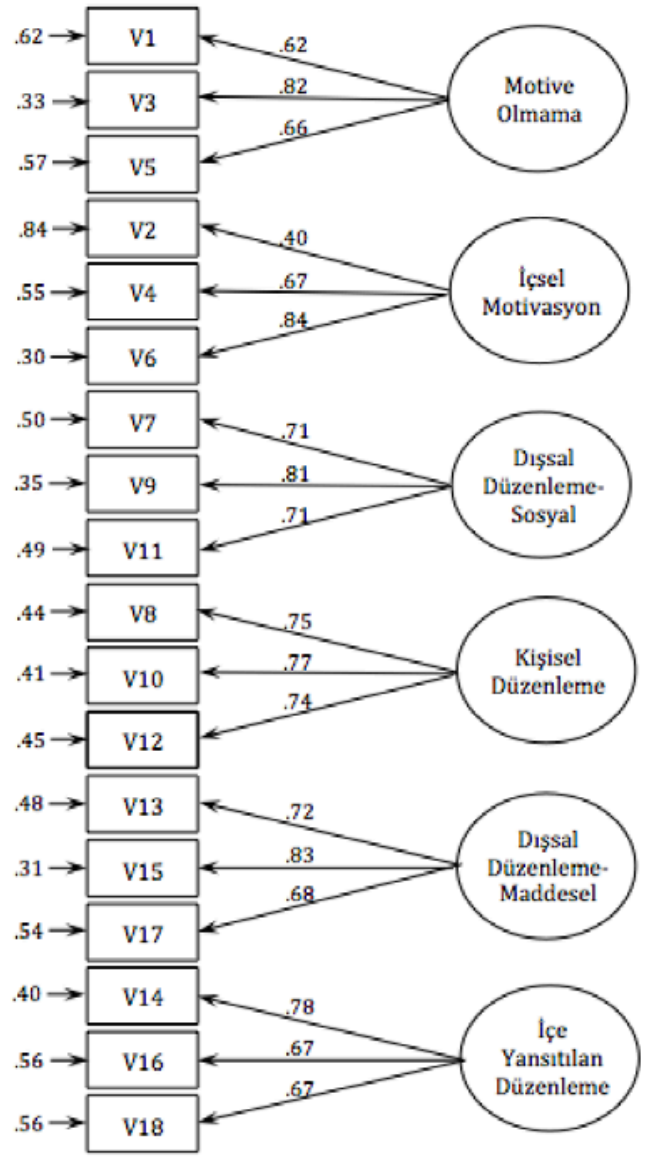

Şekil 2. Doğrulayıcı Faktör Analizi Sonuçları rına bakıldığında genel olarak orijinal kültürle aynı faktör deseninin elde edildiği sonucuna ulaşılmıştır. Maddelerin faktör yük değerlerinin ve faktörlerin açıklanan toplam varyansa olan katkılarının oldukça yüksek olduğu söylenebilir. Diğer taraftan DFA ile elde edilen bulgular doğrultusunda $\chi^{2}$ ve serbestlik derecesi oranının 3'ün altında, RMSEA değerinin .08'in altında, GFI ve AGFI değerlerinin .90'a eşit ve .90 'ın üstünde, SRMR değerinin .08 'in altında ve son olarak CFI değerinin .95'in üstünde olduğu sonucuna ulaşılmıştır. Bu sonuçların aracın İngilizce, Fransızca, Felemenkçe, Almanca, Çince formları için elde edilen uyum indeksleriyle genellikle benzer olduğu söylenebilir (Gagné et al. 2010, 2014). Bu doğrultuda araçtan elde edilen puanlar çerçevesinde kabul edilebilir düzeyde yapı geçerliliği kanıtı elde edildiği ifade edilebilir. Bu araştırmanın bir uyarlama çalışması olması nedeniyle her ne kadar iyi çalışmasa da, içe yönelik düzenleme alt ölçeğindeki 19. maddenin araçta kalması yönünde görüş bildirilebilir, çünkü bu maddenin başka örneklemlerde çalışması bir olasılıktır. Ancak uygulayıcıların bu madde bağlamında madde puanlarına dayalı bir değerlendirme yapmamaları önemlidir. Diğer taraftan iç tutarlılık bağlamında güvenilirlik kanıtları değerlendirildiğinde, belirli ölçüde kabul edilebilir güvenilirlik katsayılara ulaşıldığı düşünülebilir. Nunnaly ve Bernstein’a (1994) göre, güvenilirlik katsayısının .70-.80 aralığında olması, ölçeğin araştırmalarda kullanılması için yeterli güvenilirlik düzeyinde olduğunun göstergesidir. Madde sayısının az olması güvenilirlik katsayısını belirli ölçüde sınırlayan bir etken olabilir. Bu durumda elde edilen tüm kanıtlar doğrultusunda ÇBIMÖ’nin endüstri ve örgüt psikolojisi ve/veya örgütsel davranış araştırmala- 
rında beyaz yakalı örgüt çalışanlarının iş motivasyonlarının ölçülmesi amacıyla uygulanabileceği söylenebilir.

$\mathrm{Bu}$ araştırmada $C \zeta B \dot{I} M O ̈$, pilot uygulamada psikolog, öğretmen, otomotiv satış iş göreni, turizm iş göreni, sağlık iş göreni ve devlet memurlarına uygulanmıştır. Ölçek, asıl uygulamada ise akademisyen, öğretmen, bankacı, otomotiv satış iş göreni, turizm iş göreni ve üniversitede çalışan memurlar gibi farklı mesleklerden beyaz yakalı çalışanlara uygulanmıştır. ÇBIMMÖ’nün gerek bu araştırma kapsamında yer almayan hizmet iş kolları (muhasebeciler, mühendisler, insan kaynakları uzmanları, müşteri temsilcileri, çağrı operatörleri, emniyet görevlileri gibi), gerekse üretim, bilişim ve teknoloji gibi hizmet iş kollarının dışındaki farklı iş kollarında çalışan beyaz yakalılara da uygulanması mümkündür. Ancak bunun için araştırmacılar başka iş kollarında aracın psikometrik niteliklerini belirlemeye yönelik çalışmalar planlayabilirler.

\section{Yazarların Notu}

$\mathrm{Bu}$ araştırmada endüstri ve örgüt psikolojisi alanında kullanılmak üzere Türk kültürüne uyarlanarak, alana kazandırılan bu ölçeğin araştırmacılar tarafından bilimsel çalışmalarda kullanılması için bu çalışmayı referans olarak göstermeleri yeterlidir; ayrıca araştırmacıların yazarlardan izin almaları gerekmemektedir. Ölçek ekte sunulmuştur (Bk. Ek-1).

\section{KAYNAKÇA}

Abd-El-Salam E. M., Shawky A. Y., El-Nahas T. \& Nawar Y. S. (2013). “The Relationship Among Job Satisfaction, Motivation, Leadership, Communication, and Psychological Empowerment: An Egyptian Case Study”. SAM Advanced Management Journal (2013) 33-50.

Ağırbaş İ., Çelik Y. \& Büyükkayıkçı H. (2005). "Motivasyon Araçları ve İş Tatmini: Sosyal Sigortalar Kurumu Başkanlığı Hastane Başhekim Yardımcıları Üzerinde Bir Araştırma”. Hacettepe Sağllk Ídaresi Dergisi 8/3 (2005) 326-350.

Büyüköztürk Ş. (2011). Sosyal Bilimler İçin Veri Analizi El Kitabı: İstatistik, Araştırma Deseni, SPSS Uygulamalart ve Yorum. Ankara $2011^{13}$.

Çelik D. A. \& Telman N. (2013). Endüstri Örgüt Psikolojisi Alanında Kullanılan Ölçekler El Kitabı. Ankara 2013.

Çokluk Ö., Şekercioğlu G. \& Büyüköztürk Ş. (2016). Sosyal Bilimler İçin Çok Değişkenli Istatistik: SPSS ve LISREL Uygulamaları. Ankara $2016^{4}$.

Deci E. L. \& Ryan R. M. (2008). "Facilitating Optimal Motivation and Psychological Well- Being Across Life's Domains”. Canadian Psychology 49/1 (2008) 14-23. Doi:10.1037/0708-5591.49.1.14

Dysvik A. \& Kuvaas B. (2013). "Intrinsic and Extrinsic Motivation as Predictors of Work Effort: The Moderating Role of Achievement Goals”. British Journal of Social Psychology 52 (2013) 412-430. Doi:10.1111/j.2044-8309.2011.02090.x.

Eren E. (2008). Örgütsel Davranış ve Örgüt Psikolojisi. İstanbul 2008.

Ertaş N. (2015). "Turn Over Intentions and Work Motivations of Millennial Employees in Federal Service”. Public Personnel Management 44/3 (2015) 401-423. Doi:10.1177/0091026015588193.

Fernet C., Austin S. \& Vallerand R. J. (2012). “The Effects of Work Motivation on Employee Exhaustion and Commitment: An Extension of the JD-R model”. Work\&Stress 26/3 (2012) 213-229.

Gagné M., Forest J., Gilbert M. H., Aubé C., Morin E. \& Malorni A. (2010). "The Motivation at Work Scale: Validation Evidence in Two Languages”. Educational and Psychological Measurement 70/4 (2010) 628-646. Doi:10.1177/0013164409355698.

Gagné M., Forest J., Vansteenkiste M., Braud L. C., Broeck A.V., Aspeli A. K., Bellerose J., Benabou C., Chemolli E., Güntert S. T., Halvari H., Indiyastuti D. L., Johnson P. A., Molstad M. H., Naudin M., Ndao A., Olafsen A. H., Roussel P., Wang Z. \& Westbye C. (2014). "The Multidimensional Work Motivation Scale: Validation Evidence in Seven Languages and Nine Countries”. European Journal 
of Work and Organizational Psychology (2014) 1-19. Doi: 10.1080/1359432X.2013.877892.

Gorsuch R. L. (1974). Factor Analysis. Philadelphia 1974 ${ }^{1}$.

Guo Y., Liao J., Liao S. \& Zhang Y. (2014). “The Mediating Role of Intrinsic Motivation on There Lation Ship Between Develop Mental Feed Back and Employee Job Performance”. Social Behavior and Personality 42/5 (2014) 731-742. Doi:10.2224/Sbp.2014.42.5.731.

Güney S. (2014). Davranış bilimleri. Ankara 2014.

Hauser L. (2014). "Work Motivation in Organizational Behavior”. Economics, Management, and Financial Markets 9/4 (2014) 239-246.

Hsu L. (2013). “Work Motivation Job Burn Out, and Employ Mentaspiration in Hospitality and Tourism Students - An Exploration Using the Self-Determination Theory”. Journal of Hospitality, Leisure, Sport \& Tourism Education 13 (2013) 180-189. Doi: 10.1016/j.jhlste.2013.10.001.

Kantar H. (2008). İsletmede Motivasyon. İstanbul 2008.

Karasar N. (1994). Bilimsel Araştırma Yöntemi. Ankara $1994^{5}$.

Latham G. P. (2007). "Work Motivation History, Theory, Research and Practice”. (E-Book).

Lazaroiu G. (2015). “Employee Motivation and Job Performance”. Linguistic and Philosophical Investigations 14 (2015) 97-102.

Lee H. W. \& Liu C. H. (2009). "There Lation Ship Among Achieve Mentmotivation, Psychological Contract and Work Attitudes”. Social Behavior and Personality 37/3 (2009) 321-328. Doi: 10.2224/sbp.2009.37.3.321.

Mafini C. \& Dlodlo N. (2014). “There Lation Ship Between Extrinsic Motivation, Job Satisfaction and Life Satisfaction Amongs Temployees in a Public Organisation”. SA Journal of Industrial Psychology 40/1 (2014) 1-13. Doi: 10.4102/sajip.v40i1.1166

Mirabela M. \& Madela A. (2013). "Cultural Dimensions and Work Motivation in the European Union”. Annals of the University of Oradea, Economic Science Series 22/1 (2013) 1511-1519. Source: http://scholar.google.com.tr/scholar?hl=tr\&q=CULTURAL+DIMENSIONS+AND+WORK+MOTIV ATION+IN+THE+EUROPEAN\&btnG=\&lr= (Erişim Tarihi: 30.06.2016).

Nunnaly J. C. \& Bernstein I. H. (1994). Psychometrictheory. New York 1994³.

Padmaja K. V., Bhar S. \& Gangwar S. (2013). "Work Experience, Motivation and Satisfaction-Do They Go Together?”.The Journal of Institute of Public Enterprise 36/3-4 (2013) 49-83.

Riggio R. E. (2014). Endüstri ve Örgüt Psikolojisine Giriş. Ankara 2014.

Ryan R. M. \& Deci E. L. (2000). "Intrinsic and Extrinsic Motivations: Classic Definitions and New Directions”. Contemporary Educational Psychology 25 (2000) 54-67. Doi:10.1006/ceps.1999.1020.

Steers R. M., Mowday R. T. \& Shapiro D. L. (2004). "Introduction to Special Topic Forum the Future of Work Motivation Theory”. Academy of Management Review 29/3 (2004) 379-387.

Tabachnick B. G. \& Fidel L. S. (2015). Çok Değişkenli İstatistiklerin Kullanımı. Ankara 2013.

Toode K., Routasalo P., Helminen M. \& Suominen T. (2014). “Hospital Nurses’ Individual Priorities, Internal Psychological States and Work Motivation”. International Nursing Review 61/3 (2014) 361-370.

Vroom V. H. (1964). Work and Motivation. New York 1964. 


\section{EK 1: Çok Boyutu İş Motivasyonu Ölçeği}

\begin{tabular}{|c|c|c|c|c|c|}
\hline $\begin{array}{l}\text { Bu soru listesini “Şu anki işinizde neden çaba sarf ediyorsunuz?” } \\
\text { sorusunu düşünerek yanıtlayınız. }\end{array}$ & 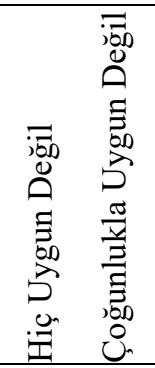 & 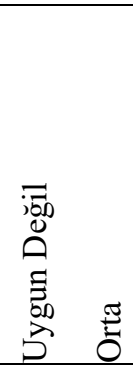 & $\begin{array}{l}\Xi \\
\Xi \\
\infty \\
\infty \\
\infty\end{array}$ & 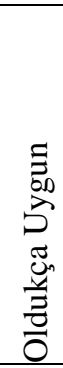 & 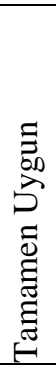 \\
\hline $\begin{array}{l}\text { 1. Zamanımı israf ettiğimi düşündüğ̈̈m için işimde çaba sarf } \\
\text { etmiyorum. }\end{array}$ & $\square \square$ & $\square \square$ & & & \\
\hline 2. İlginç olduğu için işimde çaba sarf ediyorum. & $\square \square$ & $\square \square$ & & & \\
\hline $\begin{array}{l}\text { 3. Çaba sarf etmeye değer olmadığını düşündüğüm için işimde az } \\
\text { çaba gösteriyorum. }\end{array}$ & $\square \square$ & $\square \square$ & & & \\
\hline 4. Heyecan verici olduğu için işimde çaba sarf ediyorum. & $\square \square$ & $\square \square$ & & & \\
\hline $\begin{array}{l}\text { 5. İşim anlamsız olmasına rağmen neden hala bu işi yaptığımı } \\
\text { bilmiyorum. }\end{array}$ & $\square \square$ & $\square \square$ & & & \\
\hline 6. İşimi yaparken eğlendiğim için işimde çaba sarf ediyorum. & $\square \square$ & $\square \square$ & & & \\
\hline $\begin{array}{l}\text { 7. Başkalarının (amir, meslektaş, aile vb.) onayını almak için } \\
\text { işimde çaba sarf ediyorum. }\end{array}$ & $\square \square$ & $\square \square$ & & & \\
\hline 8. İşimde çaba sarf etmenin benim için özel bir anlamı var. & $\square$ & $\square$ & & & \\
\hline $\begin{array}{l}\text { 9. Başkalarının (amir, meslektaş, aile vb.) bana daha fazla saygı } \\
\text { duyması için işimde çaba sarf ediyorum. }\end{array}$ & $\square \square$ & $\square$ & & & \\
\hline $\begin{array}{l}\text { 10. Bu iş, kişisel değerlerimle uyumlu olduğu için işimde çaba sarf } \\
\text { ediyorum. }\end{array}$ & $\square$ & $\square$ & & & \\
\hline $\begin{array}{l}\text { 11. Başkalarının (amir, meslektaş, aile vb.) bana yönelik } \\
\text { eleştirilerinden kaçınmak için işimde çaba sarf ediyorum. }\end{array}$ & $\square \square$ & $\square$ & & & \\
\hline $\begin{array}{l}\text { 12. Bu işte çaba sarf etmenin kişisel olarak önemli olduğunu } \\
\text { düşünndügüm için işimde çaba gösteriyorum. }\end{array}$ & $\square$ & $\square$ & & & \\
\hline $\begin{array}{l}\text { 13. Ancak işimde yeterince çaba sarf edersem başkaları (işveren, } \\
\text { amir vb.) beni ekonomik olarak ödüllendirirler. }\end{array}$ & $\square$ & $\square$ & & & \\
\hline 14. İşimde çaba sarf ederim aksi halde, kendimi kötü hissederim. & $\square \square$ & $\square \square$ & & & \\
\hline $\begin{array}{l}\text { 15. İşimde yeterince çaba sarf edersem başkaları (işveren, amir } \\
\text { vb.) bana daha fazla iş güvenliği sağlarlar. }\end{array}$ & $\square \square$ & $\square$ & & & \\
\hline $\begin{array}{l}\text { 16. Şimdiki işimde çaba sarf ederim aksi halde, kendimi mahcup } \\
\text { hissederim, }\end{array}$ & $\square \square$ & $\square \square$ & & & \\
\hline $\begin{array}{l}\text { 17. İşimde yeterince çaba sarf etmezsem işimi kaybetme riskim } \\
\text { olur. }\end{array}$ & $\square \square$ & $\square$ & & & \\
\hline $\begin{array}{l}\text { 18. İşim, kendimle gurur duymamı sağladığı için işimde çaba sarf } \\
\text { ediyorum. }\end{array}$ & $\square \square$ & $\square$ & $\square$ & $\square$ & $\square$ \\
\hline $\begin{array}{l}\text { 19. Kendimi kanitlamak zorunda olduğum için işimde çaba sarf } \\
\text { ediyorum. }\end{array}$ & $\square \square$ & $\square$ & $\square$ & $\square$ & \\
\hline
\end{tabular}

